\title{
Influence of acid pre-treatment on microalgal biomass for bioethanol production
}

\begin{abstract}
The utilisation of microalgal biomass as feedstock for bioethanol production has been very promising owing to the large amounts of carbohydrates embedded in the physiology of the microalgal cell. This is coupled with the potential of microalgae to achieve targets required for high growth rate bioethanol production, climate change mitigation and economic growth. The high content of complex carbohydrates entrapped in the cell wall of the microalgae makes it essential to incorporate a pre-treatment stage to release and convert these complex carbohydrates into simple sugars prior to the fermentation process. Hence, this study explores the influence of acid exposure as a microalgal pre-treatment strategy for bioethanol production. Different parameters were investigated: acid concentration, temperature, microalgae loading and pre-treatment time. A central composite design technique was employed to optimize the acid pre-treatment conditions. Results showed that the highest bioethanol concentration obtained was $7.20 \mathrm{~g} / \mathrm{L}$ and this was achieved when the pre-treatment step was performed with $15 \mathrm{~g} / \mathrm{L}$ of microalgae at $140{ }^{\circ} \mathrm{C}$ using $1 \%(\mathrm{v} / \mathrm{v})$ of sulphuric acid for $30 \mathrm{~min}$. In terms of ethanol yield, $\sim 52 \mathrm{wt} \%$ (g ethanol/g microalgae) maximum was obtained using $10 \mathrm{~g} / \mathrm{L}$ of microalgae and $3 \%(\mathrm{v} / \mathrm{v})$ of sulphuric acid under $160{ }^{\circ} \mathrm{C}$ for $15 \mathrm{~min}$. The statistical analysis revealed amongst the parameters investigated that temperature is the most critical factor during acid pre-treatment of microalgae for bioethanol production.
\end{abstract}

Keyword: Microalgae; Biomass; Acid pre-treatment; Fermentation; Bioethanol 